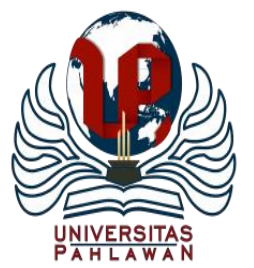

Jurnal Basicedu Volume 4 Nomor 4 Tahun 2020 Halm. 985 - 993

JURNAL BASICEDU

Research \& Learning in Elementary Education

https://jbasic.org/index.php/basicedu/index

\title{
Komparasi Model Pembelajaran Problem Based Learning Dan Teams Game Tournament Ditinjau dari Peningkatan Kemampuan Berpikir Kreatif Siswa Sekolah Dasar
}

\author{
Gita Anggreini ${ }^{1,}$ Nyoto Harjono ${ }^{2}$ \\ Universitas Kristen Satya Wacana, Jawa Tengah, Indonesia ${ }^{1,2}$ \\ E-mail : 292016066@ student.uksw.edu ${ }^{1},{\text { nyoto.harjono@ } \text { uksw.edu }^{2}}^{2}$
}

\begin{abstract}
Abstrak
Tujuan penelitian ini adalah untuk mengetahui hasil komparasi pengaruh penggunaan model pembelajaran Problem Based Learning (PBL) dan model pembelajaran Teams Game Tournament (TGT) ditinjau dari kemampuan berpikir kreatif siswa kelas V SD pada muatan IPA. Penelitian ini berjenis meta-analisis. Data penelitian diperoleh melalui berbagai jurnal ilmiah online yang minimal telah terindeks DOAJ. Dari berbagai artikel yang ditemukan melalui searching di Google, dipilih 20 artikel yang relevan untuk dianalisis. Dari hasil analisis statistik uji effect size pada kedua model pembelajaran, diperoleh nilai sig. 0.000 dengan nilai partial eta square 0.831. Angka tersebut menunjukkan bahwa kedua model pembelajaran berpengaruh sedang terhadap kemampuan berpikir kreatif IPA. Dari hasil uji ancova terhadap kedua model, diperoleh nilai mean different model PBL 73,9900 dan nilai mean different model TGT 71,1490. Hal ini membuktikan bahwa model PBL lebih tinggi peningkatannya dibandingkan dengan model TGT ditinjau dari kontribusinya dalam peningkatan kemampuan berpikir kreatif.
\end{abstract}

Kata kunci: problem based learning, teams game tournamnet, kemampuan berpikir kreatif, IPA

\begin{abstract}
The purpose of this research is to get a comparison of the impact on the use of the Problem Based Learning $(P B L)$ model and the Teams Game Tournament (TGT) model from the creative thinking students of elementary grade $V$ science content. The research is a meta-analysis type. Research data is obtained through various online scientific journals that have at least DOAJ indexed. From the various articles found through searching on Google, selected 20 relevant articles to be analyzed. From the results of statistical analysis test effect size on both learning models, obtained the value of sig. 0.000 with partial eta square value of 0.831 . The figure shows that both models of learning are influential in the creative thinking skills of science. From the test results of Ancova against both models, obtained the mean value of different PBL model 73.9900 and the value of mean different TGT model 71.1490. This proves that the PBL model is higher in its improvement than the TGT model is reviewed from its contribution in the enhancement of creative thinking skills.
\end{abstract}

Keywords: problem based learning, teams game tournamnet, creative thinking skills, science

Copyright $\odot 2020$ Gita Anggreini, Nyoto Harjono

$\triangle$ Corresponding author :

Address : Paker, Randurejo, Pulokulon, Grobogan

Email : 292016066@student.uksw.edu

Phone : 085713600194

DOI : https://doi.org/10.31004/basicedu.v4i4.486
ISSN 2580-3735 (Media Cetak)

ISSN 2580-1147 (Media Online) 


\section{PENDAHULUAN}

Ilmu Pengetahuan Alam (IPA) berhubungan dengan cara mencari tahu tentang alam secara sistematis, sehingga IPA bukan hanya penguasaan pengetahuan tentang fakta-fakta, konsep-konsep, atau prinsip-prinsip saja tetapi juga merupakan proses penemuan. Sebagai proses, IPA merupakan langkah-langkah yang ditempuh oleh ilmuan untuk melakukan penyelidikan dalam rangka mencari penjelasan tentang gejala-gejala alam (Suyudi, 2013). Langkah-langkah yang dimaksud adalah merumuskan masalah, merumuskan hipotesis, merancang eksperimen, mengumpulkan data, menganalisis, dan menyimpulkan. Pendidikan IPA diarahkan pada pendekatan inkuiri dan berbuat sehingga dapat membantu peserta didik untuk memperoleh pemahaman yang mendalam tentang alam sekitar (Permendiknas No.22 Tahun 2006 tentang Standart Isi). IPA sebagai salah satu bidang studi yang bertujuan untuk membekali siswa dalam mengembangkan pengetahuan dan keterampilan, di samping aspek penalaran dan hafalan, pengetahuan dan informasi yang diterima siswa bukan hanya sebatas pengetahuan sempit saja.

Proses pembelajaran IPA mengutamakan pada pemberian pengalaman langsung untuk mengembangkan kompetensi agar siswa memahami alam sekitar secara ilmiah. Proses belajar mengajar melibatkan aktivitas siswa secara keseluruhan, artinya melibatkan pikiran, penglihatan, pendengaran, dan keterampilan. Jadi dalam proses belajar-mengajar, guru harus mengajak siswa belajar langsung melalui lingkungan agar siswa bisa mengetahui benda- benda, menghubungkan materi yang abstrak dengan yang ada di lingkungan tempat tinggal mereka. Dengan begitu siswa akan lebih mudah memahami pembelajaran sehingga tidak terlalu kesulitan dalam memecahkan permasalahan (soal).

Pemecahan masalah memiliki hubungan erat dengan berpikir kreatif (Marcut, dalam Khamdun, 2018). Kemampuan berpikir kreatif IPA siswa akan muncul ketika ada permasalahan sebagai pemicunya (Krulik Rudnick dalam Khamdun, 2018). Dalam pembelajaran IPA melalui penyelesaian masalah siswa belajar bagaimana berpikir secara kreatif, sebaliknya untuk melatih kemampuan berpikir kreatif siswa diperlukan suatu masalah.

Selo Somardjan (dalam Munandar, 1988) menyatakan bahwa "kreativitas mulai dengan kemampuan individu untuk menciptakan sesuatu". Setiap individu memiliki potensi kreatif yang berbeda-beda dan dalam bidang yang berbeda pula, potensi tersebut perlu dikembangkan sejak dini. Kreatif dapat dipahami sebagai sifat individu yang tercermin dari kemampuannya untuk menciptakan sesuatu yang baru (Munandar, 2009). Kreativitas tidak selalu harus hal yang belum pernah ada, tetapi bisa juga meniru ide lama dengan package baru atau bisa juga dengan menambah ide baru. Kreativitas bukan hanya untuk mengembangkan karya seni, tetapi juga penemuan-penemuan dari menifestasi ide-ide, proses menghasilkan sesuatu juga termasuk dalam kreativitas.

Guilford (dalam Munandar, 2009) mengungkapkan 4 ciri-ciri orang kreatif. 1) kelancaran berpikir, kemampuan untuk 
menghasilkan ide dengan cepat; 2) keluesan berpikir, kemampuan menghasilkan ide/jawaban yang bervariasi; 3) elaborasi, kemampuan untuk menambahkan ide/gagasan dari suatu objek; 4) originalitas, kemampuan untuk menghasilkan gagasan yang unik berasal dari diri sendiri. Untuk mengembangkan potensi kreatif diperlukan faktorfaktor pendorong, baik dari eksternal (lingkungan) maupun dari diri individu sendiri. Lingkungan dapat mencakup lingkungan sempit (keluarga, sekolah) maupun luas (masyarakat, kebudayaan).

Daya kreatif individu dapat dirangsang dan dikembangkan secara sengaja melalui lingkungan sekolah, melalui proses belajar-mengajar di kelas. Banyak hal yang dapat dilakukan guru unuk merangsang kemampuan berpikir kreatif siswa. pembelajaran yang di dominasi dengan ceramah yang menekankan keaktifan guru, sebaiknya di perbaiki lagi. Salah satunya adalah dengan cara menerapkan model pembelajaran yang tepat, sehinga siswa menjadi lebih aktif, menumbuhkan rasa ingin tahu, merangsang siswa untuk menumbuhkan rasa ingin tahu, dan mengembangkan kemampuan yang dimilikinya.

Model pembelajaran PBL dan model pembelajaran TGT untuk meningkatkan kemampuan berpikir kreatif muatan IPA dirasa sesuai. Menurut Arends (dalam (Hosnan, 2014) PBL adalah "model pembelajaran dengan pendekatan pembelajaran siswa pada masalah autentik sehingga siswa dapat menyusun pengetahuannya sendiri, menumbuhkembangkan keterampilan yang lebih tinggi dan inquiry, memandirikan siswa dan meningkatkan kepercayaan diri sendiri”. Menurut Tan (dalam
(Rusman, 2013), pembelajaran berbasis masalah "merupakan inovasi dalam pembelajaran karena dalam PBM kemampuan berpikir siswa benarbenar dioptimalisasikan melalui proses kerja kelompok atau tim yang sistematis, sehingga siswa dapat memberdayakan, mengasah, menguji, dan mengembangkan kemampuan berpikirnya secara berkesinambungan”. Model Pembelajaran Problem Based Learning menghadapkan langsung siswa pada masalah, dimana masalah ini sangat berkaitan dengan kemampuan berpikir kreatif.

Kegiatan model PBL menurut Nur (dalam (Hosnan, 2014): 1. Mengorientasikan siswa terhadap masalah; 2. Mengorientasi siswa untuk belajae; 3. Membimbing penyelidikan individu maupun kelompok; 4. Mengembangkan dan menyajikan hasil karya; 5. Menganalisis dan mengevaluasi proses pemecahan masalah. Dari kegiatan tersebut sangat mendukung siswa untuk meningkatkan kemampuan berpikir kreatif mereka.

Model pembelajaran TGT merupakan salah satu tipe model kooperatif yang memfasilitasi siswa belajar di dalam kelompok. (Slavin, 2015) mendefinisikan model pembelajaran TGT sebagai turnamen akademik yang menggunakan kuis-kuis dan sisem skor kemajuan individu dimana siswa berlomba mewakili tim mereka dengan tim lain yang kinerja ademiknya setara. (Shoimin, 2014) menyatakan badwa Model pembelajaran TGT merupakan model pembelajaran kooperatif yang melibatkan aktivitas seluruh siswa tanpa harus ada perbedaan status, melibatkan peran siswa sebagai tutor sebaya dan mengandung unsur permainan dan renforcement. Model pembelajaran TGT memungkinkan siswa dapat belajar bertanggung 
jawab, menambah motivasi, dan rasa percaya diri, tidak bergantung pada guru, mengembangkan kemampuan mengungkapkan ide, saling bertukar pikiran, saling menghargai, kompetitif, kerja sama, dan keterlibatan belajar.

(Shoimin, 2014) menyatakan langkahlangkah model pembelajaran TGT, yaitu: 1 . Pesentasi kelas, guru menyampaikan materi; 2. Kelompok, siswa membentuk kelompok dan belajar besama kelompok masing-masing; 3 . Permainan, siswa melakukan permainan dengan kelompok lain untuk memperoleh skor; 4. Turnamen, dari nilai yang telah dikumpulkan ditentukan pemenang permainan; 5. Penghargaan kelompok, setiap kelompok mendapat penghargaan dari guru berdasarkan jenis kategori yang mereka menangkan.

Dari uraian diatas, tampak bahwa ketelibatan siswa untuk turut belajar dengan menerapkan model pembelajaran PBL dan TGT merupakan salah satu indikator keefektifan belajar. Siswa tidak hanya menerima saja materi dari guru, melainkan juga berupaya untuk menggali dan mengembangkan sendiri informasi. Hasil belajar tidak hanya menghasilkan pengetahuan yang meningkat tetapi juga meningkatkan kemampuan berpikir siswa. Kemampuan siswa dalam menyelesaikan soal dapat dilihat dari cara ia melakukan dan menjelaskan proses kegiatan sehingga diperoleh kesimpulan atau jawaban masalah. Dengan penerapan model pembelajaran PBL dan TGT dapat melatih siswa belajar aktif, kreatif, dan meningkatkan keterampilan siswa.

Penelitian ini bertujuan untuk mengetahui komparasi pengaruh penggunaan model pembelajaran PBL dan model pembelajaran TGT Ditijau dari Peningkatan Kemampuan Berpikir Kreatif Siswa SD Pada Muatan IPA dari berbagai penelitian eksperimen yang dipublikasikan.

\section{METODE}

Metode penelitian yang digunakan dalam penelitian ini adalah meta-analisis. Meta-analisis merupakan metode penelitian yang mengkombinasikan dan menganalisis hasil-hasil penelitian sejenis dan mengujinya untuk memperoleh generalisasi (Punaji, 2014). Data dikumpulkan dengan menelusui jurnal online, repository, dan google scholar. Dari hasil pengumpulan diperoleh 20 artikel untuk dianalisis. Populasi dari penelitian ini adalah artikel yang sudah dipublikasikan. Sampel pada penelitian ini adalah artikel dari jurnal dengan kriteria (1) subjek penelitian berupa penggunaan model pembelajaran PBL dan TGT ditinjau dari kemampuan berpikir kreatif; (2) penelitian dilakukan pada jenjang pendidikan SD/MI; (3) penelitian dilakukan dalam rentang tahun 2009-2020; (4) isi artikel memenuhi data yang dibutuhkan untuk menghitung effect size. Dari hail penelusuran diperoleh 10 sampel model pembelajaran PBL dan 10 sampel model TGT.

Instrumen penelitian merupakan alat yang digunakan untuk mengumpulkan data. Instrumen yang digunakan dalam penelitian ini adalah lembar data cooding, untuk mengumpulkan data pengaruh mode pembelajaran PBL dan TGT ditinjau dari kemampuan berpikir kratif siswa SD pada muatan IPA. Teknik analisis data yang digunakan dalam penelitian ini adalah penghitungan besar pengaruh 
atau effect size. Effect size merupakan sebuah metode untuk mengetahui besar pengaruh keefektifan dari model pembelajaran. Effect size dalam statistik digunakan untuk menentukan besarnya skala keefektifan sebuah penelitian. Data yang digunakan adalah hasil rata-rata pretestposstest kemampuan berpikir kreatif dari artikel yang telah dianalisis. Nilai pretest-posstest diperoleh dari hasil soal tes urain dengan indikator kemampuan berpikir kreatif.

\section{HASIL DAN PEMBAHASAN}

Artikel yang dianalisis diperoleh sebanyak dua puluh. Data dari artikel-artikel tersebut dianalisis untuk menentukan hasil penelitian yang dibutuhkan berupa skor rata-rata pretest dan posttes pada model PBL dan TGT dalam meningkatkan kemampuan berpikir kreatif. Dari hasil skor rata-rata pretest dan posttes kemudian diperoleh data sebagai berikut:

Tabel 1. Persentase Peningkatan Berpikir Kreatif Model PBL

\begin{tabular}{ccccc}
\hline & \multicolumn{4}{c}{ Persentase (\%) } \\
\cline { 2 - 5 } No & $\begin{array}{c}\text { Kode } \\
\text { Data }\end{array}$ & $\begin{array}{c}\text { Skor } \\
\text { Pretest }\end{array}$ & $\begin{array}{c}\text { Skor } \\
\text { Posttest }\end{array}$ & $\begin{array}{c}\text { Pening- } \\
\text { katan }\end{array}$ \\
\hline 1. & P1 & 79,61 & 91,67 & 12,06 \\
2. & P2 & 63,00 & 80,00 & 17,00 \\
3. & P3 & 10,20 & 19,88 & 9,68 \\
4. & P4 & 67,22 & 76,91 & 9,69 \\
5. & P5 & 70,01 & 80,14 & 10,13 \\
6. & P6 & 66,00 & 79,00 & 13,00 \\
7. & P7 & 76,31 & 84,10 & 7,79 \\
8. & P8 & 69,64 & 83,93 & 14,29 \\
9. & P9 & 52,69 & 63,96 & 11,27 \\
10. & P10 & 77,47 & 80,31 & 2,84 \\
& Mean & 63,215 & 73,99 & 10,775 \\
\hline
\end{tabular}

Dari tabel 4.1 dapat dilhat peningkatan kemampuan berpikir kreatif menggunakan model pembelajaran PBL dari perentase rata-rata nilai pretest dan posttest. Persentase rata-rata peningkatan kemampuan berpikir kreatif siswa dengan menggunakan model pembelajaran PBL mulai dari yang terendah yaitu 2,84\% sampai yang tertinggi $14,29 \%$ dengan rata-rata keseluruhan peningkatan kemampuan berpikir kreatif 10,775\%. Rata-rata persentase pre-test $63,215 \%$ setelah di terapkan pembelajaran menggunakan model PBL meningkat menjadi $73,99 \%$. Nilai rata-rata sebelum menggunakan model PBL dan setelah menggunakan model PBL mengalami peningkatan signifikan sebesar $10,775 \%$.

Tabel 2. Persentase Peningkatan Berpikir Kreatif Model TGT

\begin{tabular}{ccccc}
\hline & \multicolumn{4}{c}{ Persentase (\%) } \\
\cline { 2 - 5 } No & $\begin{array}{c}\text { Kode } \\
\text { Data }\end{array}$ & $\begin{array}{c}\text { Skor } \\
\text { Pretest }\end{array}$ & $\begin{array}{c}\text { Skor } \\
\text { Posttest }\end{array}$ & $\begin{array}{c}\text { Peningk- } \\
\text { atan }\end{array}$ \\
\hline 1. & T1 & 70,07 & 81,93 & 11,86 \\
2. & T2 & 63,00 & 82,00 & 19,00 \\
3. & T3 & 40,27 & 78,13 & 37,86 \\
4. & T4 & 2,08 & 2,17 & 0,09 \\
5. & T5 & 50,80 & 74,00 & 23,20 \\
6. & T6 & 58,95 & 76,00 & 17,05 \\
7. & T7 & 40,08 & 79,60 & 39,52 \\
8. & T8 & 70,50 & 87,19 & 16,69 \\
9. & T9 & 40,08 & 76,66 & 36,58 \\
10. & T10 & 52,45 & 73,81 & 21,36 \\
& Mean & 48,828 & 71,149 & 22,321 \\
\hline
\end{tabular}

Dari tabel 4.2 dapat dilhat peningkatan kemampuan berpikir kreatif menggunakan model pembelajaran TGT dari perentase rata-rata nilai pretest dan posttest. Persentase rata-rata peningkatan kemampuan berpikir kreatif siswa dengan menggunakan model pembelajaran TGT 

dari Peningkatan Kemampuan Berpikir Kreatif Siswa Sekolah Dasar- Gita Anggreini, Nyoto Harjono DOI: https://doi.org/10.31004/basicedu.v4i4.486

mulai dari yang terendah yaitu $0,09 \%$ sampai yang tertinggi $39,52 \%$ dengan rata-rata keseluruhan peningkatan kemampuan berpikir kreatif $22,321 \%$. Rata-rata persentase pre-test $48,828 \%$ setelah di terapkan pembelajaran menggunakan model TGT meningkat menjadi $71,149 \%$. Nilai rata-rata sebelum menggunakan model TGT dan setelah menggunakan model TGT mengalami peningkatan signifikan sebesar $22,321 \%$.

Tabel 3. Komparasi Hasil Pengukuran Kemampuan Berpikir Kreatif

\begin{tabular}{cccc}
\hline Pengukuran & \multicolumn{2}{c}{$\begin{array}{c}\text { Rata-Rata Skor } \\
\text { (Mean) }\end{array}$} & Selisih \\
\cline { 2 - 3 } & PBL & \multicolumn{1}{c}{ TGT } & \\
\hline Pretest & $63,21 \%$ & $48,83 \%$ & $14,3 \%$ \\
Posttest & $73,99 \%$ & $71,15 \%$ & $2,84 \%$ \\
\hline
\end{tabular}

Berdasarkan hasil data komparasi pengukuran kemampuan berpikir kreatif pada tabel 4.3, menunjukkan bahwa persentase rata-rata skor pre-test antara model pembelajaran PBL dan TGT mempunyai selisih sebesar 14,39\%. Persentase rata-rata skor post-test antara model pembelajaran PBL dan TGT mempunyai selisih sebesar 2,84\%. Dengan demikian dapat diketahui adanya peningkatan pada model pembelajaran PBL maupun model pembelajaran TGT.

\section{Hasil Analisis Uji Ancova}

Tabel 4. Hasil Analisis Uji Ancova Descriptive Statistics

Dependent Variable:postes

\begin{tabular}{|l|r|r|r|}
\hline & Mean & Std. Deviation & N \\
\hline Model PBL & 73.9900 & 20.24737 & 10 \\
Model TGT & 71.1490 & 24.58242 & 10 \\
\hline
\end{tabular}

\section{Descriptive Statistics}

Dependent Variable:postes

\begin{tabular}{|l|r|r|r|}
\hline Model & Mean & Std. Deviation & N \\
\hline Model PBL & 73.9900 & 20.24737 & 10 \\
Model TGT & 71.1490 & 24.58242 & 10 \\
Total & 72.5695 & 21.96722 & 20 \\
\hline
\end{tabular}

Berdasarkan tabel 4.4 hasil analisis data uji ancova diperoleh nilai rata-rata dari model PBL dan model TGT. Nilai rata-rata tertinggi adalah model pembelajaran PBL 73,9900. Sedangkan rata-rata model pembelajaran TGT lebih rendah 71,1490 . Sehingga peningkatan kemampuan berpikir kreatif model PBL lebih tinggi dibandingkan dengan model TGT dengan selisih 2,84 .

\section{Tabel 5. Hasil Uji Homogenitas}

\section{Levene's Test of Equality of Error Variances ${ }^{a}$}

Dependent Variable:postes

\begin{tabular}{|c|c|c|c|}
\hline$F$ & df1 & $\mathrm{df2}$ & Sig. \\
\hline 8.050 & 1 & 18 & .875 \\
\hline
\end{tabular}

Tests the null hypothesis that the error variance of the dependent variable is equal across groups.

a. Design: Intercept + pretes + Model

Uji Levene's test bertujuan untuk mengetahui varian data yang dimiliki sama atau berbeda. Jikan nilai sig. $>0.05$ maka varian data dikatakan sama. Jika, nilai sig. $<0.05$ maka varian data dikatakan tidak sama. Nilai sig. yang diperoleh 0.875 sehingga dapat dikatakan varian sama. Karena data memiliki varian yang sama maka uji ancova dapat dilakukan. 
Tabel 6. Hasil Uji Ancova

Tests of Between-Subjects Effects

Dependent

Variable:postes

\begin{tabular}{|c|c|c|c|c|c|c|}
\hline Source & $\begin{array}{l}\text { Type III } \\
\text { Sum of } \\
\text { Squares }\end{array}$ & Df & $\begin{array}{c}\text { Mean } \\
\text { Square }\end{array}$ & $\mathrm{F}$ & Sig. & $\begin{array}{c}\text { Partial } \\
\text { Eta } \\
\text { Squared }\end{array}$ \\
\hline $\begin{array}{l}\text { Corrected } \\
\text { Model }\end{array}$ & $7621.679^{\mathrm{a}}$ & 2 & 3810.840 & 41.879 & .000 & .831 \\
\hline Intercept & 508.360 & 1 & 508.360 & 5.587 & .030 & .247 \\
\hline Pretes & 7581.323 & 1 & 7581.323 & 83.315 & .000 & .831 \\
\hline Model & 609.180 & 1 & 609.180 & 6.695 & .019 & .283 \\
\hline Error & 1546.936 & 17 & 90.996 & & & \\
\hline Total & 114495.262 & 20 & & & & \\
\hline Corrected & 9168.615 & 19 & & & & \\
\hline Total & & & & & & \\
\hline
\end{tabular}

a. R Squared $=, 831$ (Adjusted $\mathrm{R}$

Squared $=, 811$ )

Berdasarkan hasil uji ancova pada tabel 4.6 diperoleh nilai sig. untuk model pembelajaran sebesar 0.019. karena nilai sig. < 0.05 maka Ho ditolak. Sehingga dapat disimpulkan bahwa terdapat perbedaan yang signifikan pada penggunaan model PBL dan TGT ditinjau dari kemampuan berpikir kreatif siswa.

\section{Perhitungan Effect Size}

Effect size digunakan untuk mengetahui besarnya skala kefektifan dari penelitian yang telah dilakukan. Interpretasi effect yang di jadikan acuan adalah dari Cohen's d (2000), sebagai berikut:

\begin{tabular}{|c|c|}
\hline Size & Interpretation \\
\hline $0.8<\mathrm{d}<2.0$ & Big \\
\hline $0.5<\mathrm{d}<0.8$ & Average \\
\hline $0.2<\mathrm{d}<0.5$ & Small \\
\hline
\end{tabular}

(Cohen's d, 2000)
Tabel 7. Hasil Uji Effect Size dengan Uji Ancova

Tests of Between-Subjects Effects

Dependent

Variable:postes

\begin{tabular}{|c|c|c|c|c|c|c|}
\hline Source & $\begin{array}{l}\text { Type III } \\
\text { Sum of } \\
\text { Squares }\end{array}$ & $\begin{array}{l}D \\
f\end{array}$ & $\begin{array}{l}\text { Mean } \\
\text { Square }\end{array}$ & $\mathrm{F}$ & Sig & $\begin{array}{c}\text { Partial } \\
\text { Eta } \\
\text { Square } \\
\text { d }\end{array}$ \\
\hline $\begin{array}{l}\text { Correcte } \\
\text { d Model }\end{array}$ & $7621.679^{a}$ & 2 & $\begin{array}{r}3810.84 \\
0\end{array}$ & $\begin{array}{r}41.87 \\
9\end{array}$ & $\begin{array}{r}.00 \\
0\end{array}$ & .83 \\
\hline $\begin{array}{l}\text { Intercep } \\
t\end{array}$ & 508.360 & 1 & 508.360 & 5.587 & $\begin{array}{r}.03 \\
0\end{array}$ & .247 \\
\hline Pretes & 7581.323 & 1 & $\begin{array}{r}7581.32 \\
3\end{array}$ & $\begin{array}{r}83.31 \\
5\end{array}$ & $\begin{array}{r}.00 \\
0\end{array}$ & .831 \\
\hline Model & 609.180 & 1 & 609.180 & 6.695 & $\begin{array}{r}.01 \\
9\end{array}$ & .283 \\
\hline Error & 1546.936 & $\begin{array}{l}1 \\
7\end{array}$ & 90.996 & & & \\
\hline Total & $\begin{array}{r}114495.2 \\
62\end{array}$ & $\begin{array}{l}2 \\
0\end{array}$ & & & & \\
\hline $\begin{array}{l}\text { Correcte } \\
\text { d Total }\end{array}$ & 9168.615 & $\begin{array}{l}1 \\
9\end{array}$ & & & & \\
\hline
\end{tabular}

a. $\mathrm{R}$ Squared $=, 831$ (Adjusted

$\mathrm{R}$ Squared $=, 811$ )

Berdasarkan tabel 4.7 menunjukkan hasil uji effect size menggunakan uji ancova pada model pembelajaran PBL dan TGT diperoleh nilai partial eta squared pada kolom corrected model sebesar 0.831 dengan nilai sig. 0.000. hal ini berarti bahwa model pembelajaran PBL dan TGT memberikan pengaruh yang tergolong sedang terhadap kemampuan berpikir kreatif IPA.

\section{Pembahasan}

Meta-analisis dilakukan dengan mengumpulkan artikel yang sesuai dengan pembahasan. Berdasarkan hasil penelitian pada 20 artikel tentang penggunaan model PBL dan model 
TGT yang telah dianalisis, dilakukan uji effect size pada model PBL dan TGT untuk mengetahui pengaruh kedua model terhadap kemampuan berpikir kreatif IPA. Dari hasil analisis uji effect size menggunakan uji ancova diperoleh nilai partial eta square sebesar 0.831. angka tersebut berarti menunjukkan bahwa kedua model pembelajaran berpengaruh sedang terhadap kemampuan berpikir kreatif IPA. Dari hasil uji ancova model PBL dan TGT diperoleh nilai mean different model PBL 73,9900 dan nilai mean different model TGT 71,1490. Hal ini berarti model PBL lebih tinggi pengaruhnyadibandingkan dengan model TGT dengan selihih sebesar 2,84.

Hal itu sejalan dengan pemikiran Arends (dalam (Hosnan, 2014) bahwa model PBL adalah "model pembelajaran dengan pendekatan pembelajaran siswa pada masalah autentik sehingga siswa dapat menyusun pengetahuannya sendiri, menumbuhkembangkan keterampilan yang lebih tinggi dan inquiry, memandirikan siswa dan meningkatkan kepercayaan diri sendiri”. Dan pendapat dari Krulik Rudnick (dalam (Somakim, 2011) bahwa kemampuan berpikir kreatif IPA siswa akan muncul ketika ada permasalahan sebagai pemicunya. Dari hasil penelitian yang telah dilakukan oleh Nanda Noor Fadjrin menunjukkan bahwa model PBL lebih besar pengaruhnya terhadap kemampuan berpikir kreatif siswa. Penerapan model pembelajaran PBL dan TGT keduanya dapat dijadikan alternatif untuk mengembangkan kemampuan berpikir kreatif siswa pada muatan IPA. Dari hasil analisis kedua model memberikan effect yang sedang terhadap kemampuan berpikir kreatif siswa.

\section{SIMPULAN}

Berdasarkan hasil pembahasan, dapat disimpulkan bahwa penggunaan model PBL dan TGT berpengaruh terhadap peningkatan kemampuan berpikir kreatif siswa kelas V SD pada muatan IPA. Hal ini dapat dilihat dari hasil uji effect size pada tabel tests of between-subjects effects didapatkan hasil pertial eta square pada pengaruh kedua model pembelajaran sebesar 0.831 dengan nilai sig. 0.000 , yang berarti kedua model berpengaruh sedang terhadap kemampuan berpikir kreatif siswa atau dapat dikategorikan Average effect. Serta dari hasil uji ancova model PBL dan TGT diperoleh nilai mean different model PBL 73,9900 dan nilai mean different model TGT 71,1490 . Hal ini berarti model PBL lebih tinggi pengaruhnya dibandingkan dengan model TGT dengan selisih sebesar 2,84.

\section{DAFTAR PUSTAKA}

Hosnan. (2014). Pembelajaran Saintifik dan Kontekstual dalam Pembelajaran Abad 21. Bogor: Ghalia Indonesia.

Jayadinata, A. K., Isrok'atun, \& Abdurozak. (2016). Pengaruh Model Problem Based Learning Terhadap Kemampuan Berpikir Kreatif Siswa. Jurnal Pena Ilmiah, 1(1), 871-880.

Khamdun. (2018). Penggunaan Model PBL Untuk Meningkatkan Kemampuan Berpikir Kreatif. PGSD UMK, 331-337.

Khikmawati, N., \& Hidayat, T. (2019). Pengaruh Model Pembelajaran Team Games Tournament Terhadap Berpikir Kreatif dan Hasil Belajar Siswa Pada Mata Pelajaran IPA Kelas V Sd Al- Islah Surabaya. Educationa and Human Development Journal, 4(1), 6371.

Munandar. (1988). Kreativitas Sepanjang Masa. Jakarta: Pustaka Sinar Harapan. 
Munandar. (2009). Perkembangan Kreativitas Anak Berbakat. Jakarta: Rineka Cipta.

Noor, N., Retno, D., \& Saputro, S. (2015). Eksperimentasi Model Problem Based Learning ( PBL ) dan Model Kooperatif Tipe Teams Games Tournament ( TGT ) Pada Materi Dimensi Tiga Ditinjau Dari Kemampuan Berpikir Kreatif Siswa ( KBK ). Jurnal Elektonik Pembelajaran Matematika, 3(9), 1009-1020.

Nurfajriyah, D., Aeni, A. N., \& Jayadinata, A. K. (2016). Pengaruh Model Problem Based Learning Terhadap Kemampuan Berpikir Kreatif Siswa Pada Materi Pesawat Sederhana. 1(1), 251-260.

Punaji. (2014). Penelitian Pendidikan dan Pengembangan. Jakarta: Kencana Prenadamedia Group.

Purwati, Dwijananti, P., \& Mosik. (2013). Implementasi Teams Game Tournamnet Berbasis Percobaan Fisika Terhadap Kemampuan Berpikir Kreatif dan Hasil Belajar Peserta Didik. UPEJ, 2(1), 46-53.

Rusman. (2013). Model -Model Pembelajaran Mengembangkan Profesionalisme Guru. Jakarta: Rajagrafindo Persada.

Sekar, D. K. S., Pudjawan, K., \& I GD Margunayasa. (2015). Analisis Kemampuan Berpikir Kreatif Dalam Pembelajaran IPA Pada Siswa Kelas IV Di SD Negeri 2 Pamorang Kecamatan Buleleng. PGSD Universitas Pendidikan Ganesa, 3(1).

Shoimin. (2014). 68 Model Pembelajaran Inovatif Kurikulum 2013. Yogyakarta: Ar-Ruzz Media.

Slavin. (2015). Cooperative Learning. Bandung: Nusa Media.

Somakim. (2011). Peningkatan Kemampuan Berpikir Kreatif Matematis Siswa Dengan Pendidikan Matematika Realistik. Jurnal Forum MIPA, 4(1), 42-48.

Suyudi. (2013). Strategi Pemelajaran Pendidikan Karakter. Bandung: Remaja Rosdakaya. 